\title{
Kebangkitan Party ID: Analisis Perilaku Memilih dalam Politik Lokal di Indonesia
}

\author{
Haryanto
}

\begin{abstract}
This article explains that the party identification (party ID) has become the main factor of voting behavior in local politics in Indonesia. Voters no longer dominant consider the proximity factor, both ethnic and regional proximity in determining vote choice, as a general conclusion that has been used to explain voting behavioral in local politics in Indonesia. This article confirms that voters tend to conform to the party then make a choice their voices to candidates that are offered by the party.
\end{abstract}

\section{Keywords:}

voting behavioral; party ID; local politics

\begin{abstract}
Abstrak
Artikel ini menjelaskan bahwa identifikasi partai (party ID) telah menjadi faktor utama perilaku memilih dalam politik lokal di Indonesia. Pemilih tidak lagi dominan melihat faktor kedekatan (proximity), baik kedekatan etnis maupun daerah dalam menentukan pilihan suara, sebagaimana kesimpulan umum yang selama ini digunakan untuk menjelaskan perilaku memilih dalam politik lokal di Indonesia. Artikel ini menegaskan bahwa pemilih cenderung mengindentikkan diri dengan partai, kemudian menentukan pilihan suaranya kepada kandidat yang diusung oleh partainya.
\end{abstract}

\section{Kata kunci:}

perilaku memilih; party ID; politik lokal

\section{Pendahuluan}

Tulisan ini tentang perilaku memilih dalam politik lokal kontemporer. Melalui pendekatan psikologis dalam model voting behavior, tulisan ini menyatakan bahwa identifikasi partai memengaruhi posisi optimal perilaku memilih yang selama ini jarang digunakan oleh ilmuwan politik untuk menjelaskan karakteristik elektoral dalam politik lokal di Indonesia (Liddle dan Mujani, 2007; Mujani, et al., 2012). Kebanyakan studi yang ada lebih melihat variabel socio-religious, socio-cultural, ataupun sosio-economic (Gaffar, 1992; King, 2003; Ananta, et al., 2004). Sementara itu, tulisan ini menggambarkan orientasi pemilih terhadap politik dipengaruhi oleh loyalitas partisan (kedekatan pada partai politik) yang terbangun sejak lama, dan kekuatan jangka pendek seperti popularitas kandidat berdasarkan agenda kebijakan. Adapun lokus penelitian pada pelaksanaan Pemilihan Gubernur (Pilgub) Sulawesi Selatan tahun 2013 dengan fokus pada dua kabupaten di wilayah provinsi tersebut.

\footnotetext{
- Staf Pengajar Program Studi Ilmu Pemerintahan FISIP Universitas Hasanuddin Makassar Email: harymusi@gmail.com
} 
Sejak reformasi bergulir tahun 1999 dan dalam tiga rangkaian Pemilu nasional terakhir (legislatif dan presiden), ilmuwan telah menawarkan bukti kuat bahwa faktor penentu yang paling penting dari perilaku memilih di Indonesia telah bergerak pada faktor-faktor psikologis dan ekonomi politik (pilihan rasional) (Mujani, et al., 2012). Kalau persepsinya positif, pemilih cenderung memilih presiden atau partai yang sedang berkuasa, sebaliknya kalau persepsinya negatif, pemilih cenderung memilih calon presiden atau partai yang dianggap oposisi. Penemuan ini bertolak belakang dengan conventional wisdom (kepercayaan umum) sebelumnya, bahwa kebanyakan pemilih di Indonesia didorong oleh faktor-faktor agama, kedaerahan, etnis, dan kelas sosial sebagaimana dalam model perilaku memilih sosiologis (Liddle, 2012: 155). Namun, Liddle menyimpulkan bahwa politik aliran yang selama ini diyakini sebagai pendekatan sosiologis, hanya cocok dikaji pada ranah politik lokal (Mujani, et al., 2012; Liddle, 2012). Simpulan tersebut sebagaimana tesis umum dalam politik lokal, bahwa determinasi sosial budaya telah menjadi bagian dari dilema politik di Indonesia (Nordholt, 2005: 67), termasuk mengenai perilaku memilih (Erman, 2007; Hanif, 2009). Pertanyaannya kemudian, apakah gagasan konsepsi sosiologis begitu dominan menentukan pilihan politik dalam ranah lokal? Apakah studi politik benar-benar tidak harus meninggalkan pendekatan sosiologis dan beralih pada pendekatan psikologis dan pilihan rasional dalam mengkaji perilaku memilih lokal di Indonesia. Puncaknya, apakah ada kaitan secara relevan antara orientasi nasional dan orientasi lokal dalam politik, antara kandidat/partai dan pemilih khususnya menjelang rangkaian pemilu legislatif dan Pilpres mendatang?

Untukitu, melalui basis analisis geopolitik, profil sosiologis, dan statistik perolehan suara, tulisan ini mencoba membuktikan bahwa politik lokal kontemporer dalam kajian perilaku memilih telah beranjak pada faktor psikologis-sebuah perspektif dalam kajian perilaku memilih di Indonesia yang belum populer sebagai kesimpulan. Akan tetapi, secara umum telah mulai diminati dengan berbagai kritikan terhadap pendekatan sosiologis dengan menyimpulkan melemahnya politik aliran di Indonesia (Ufen, 2008: 20). Dua studi di Kabupaten Luwu Timur dan Kabupaten Pinrang menjelaskan faktor dominan yang memengaruhi pilihan suara berdasarkan kedekatan pada partai politik. Walaupun kandidat menggunakan representasi kedaerahan dan etnis dalam menentukan komposisi pasangan calon, terbukti tidak begitu signifikan terhadap perolehan suara mereka. Di dua kabupaten yang diteliti nampak jelas adanya straight-ticket voting, dimana hampir dipastikan bahwa warga yang memilih dalam partai koalisi, juga memilih kandidat pasangan yang diusung. Singkatnya, identifikasi partai telah menemukan "jati dirinya" sebagai bagian penting untuk memenangkan suara dalam ranah lokal kontemporer. Identifikasi yang dimaksud disini, akan lebih fokus pada pemilih partai yang memilih pasangan yang menang dalam Pilgub.

\section{Model Perilaku Memilih}

Setidaknya terdapat tiga pendekatan yang selama ini menjadi basis dalam membaca perilaku memilih yaitu The Columbia Study, The Michigan Model, dan Rational Choice (Bartels, 2012; Roth, 2008). Ketiga pendekatan tersebut lebih dikenal dengan istilah sosiologis, psikologis dan pilihan rasional. Selain itu, terdapat juga pendekatan berbeda yang dikembangkan oleh Lau dan Redlawsk (2006) yakni rational choice, early socialization, fast and frugal, dan bounded rationality. Dalam tulisan ini, hanya menguraikan secara singkat ketiga pendekatan pertama sebagai landasan memahami voting behavior dalam kasus yang diteliti.

The Columbia Study dipelopori oleh Lezarsfeild pada tahun 1940. The Columbia 
Study kemudian lebih dikenal dengan model atau pendekatan sosiologis. Pendekatan sosiologis memperlihatkan bahwa ada pengaruh antara nilai-nilai sosiologis yang menempel pada diri individu yang memengaruhi perilaku seseorang dalam politik. Nilai-nilai sosiologis tersebut berupa agama, kelas sosial, etnis, daerah, tradisi keluarga dan lain-lain (Bartels, 2012: 240).

Berangkat dari teori lingkaran sosial, setiap manusia terikat dalam berbagai lingkaran sosial seperti misalnya keluarga, tempat kerja, pertemanan dan lain sebagainya, teori ini kemudian digunakan untuk menjelaskan perilaku memilih. Asumsinya bahwa seorang pemilih hidup dalam konteks tertentu: status ekonominya, agamanya, tempat tinggalnya, pekerjaan dan usianya, sehingga mendefinisikan lingkaran sosial yang memengaruhi keputusan pemilih, disebabkan kontrol dan tekanan sosialnya (Roth, 2008: 24). Menurut Roth (2008: 37), model sosiologis dapat memberi penjelasan yang sangat baik pada perilaku memilih yang konstan. Hal ini disebabkan kerangka struktural masing-masing individu yang hanya berubah secara perlahan. Namun, model sosiologis tidak dapat menjelaskan mengenai penyebab pindahnya pilihan politik individu. Hal ini dapat dipahami mengingat bahwa basis analisis utama dari model ini adalah kondisi sosial, bukan menjadikan individu sebagai pusat analisis. Adapun instrumen yang menjadi basis analisis sosiologis yakni agama, etnis, pendidikan, tempat tinggal (desakota), pekerjaan, gender, umur dsb (Mujani et al., 2012). Begitu halnya dengan geopolitik (kedaerahan), juga merupakan basis analisa perilaku politik dalam model sosiologis.

Pendekatan perilaku memilih selanjutnya yakni The Michigan Model, sebuah metode untuk mengetahui perilaku memilih yang berkembang awal tahun 1950-an. The Michigan Model kemudian dikenal dengan nama pendekatan psikologis yang uraiannya secara lengkap dapat dilihat dalam "The American Voter" (1960) ditulis oleh Campbell, Converse, Miller, dan Stokes. Berbeda dengan model sosiologis, dalam model psikologis, adanya keterikatan/ dorongan psikologis yang membentuk orientasi politik seseorang. Ikatan psikologis tersebut disebabkan oleh adanya perasaan kedekatan dengan partai atau kandidat. Persepsi dan penilaian individu terhadap kandidat atau tema-tema yang diangkat (pengaruh jangka pendek) sangat berpengaruh terhadap pilihan pemilu. Secara sederhana menurut Roth (2008: 38), pendekatan psikologis berusaha untuk menerangkan faktor-faktor apa saja yang

\section{Gambar 1.}

\section{Funnel Causality (diadaptasi dari Campbell et al., 1960 oleh Dalton, 2002)}

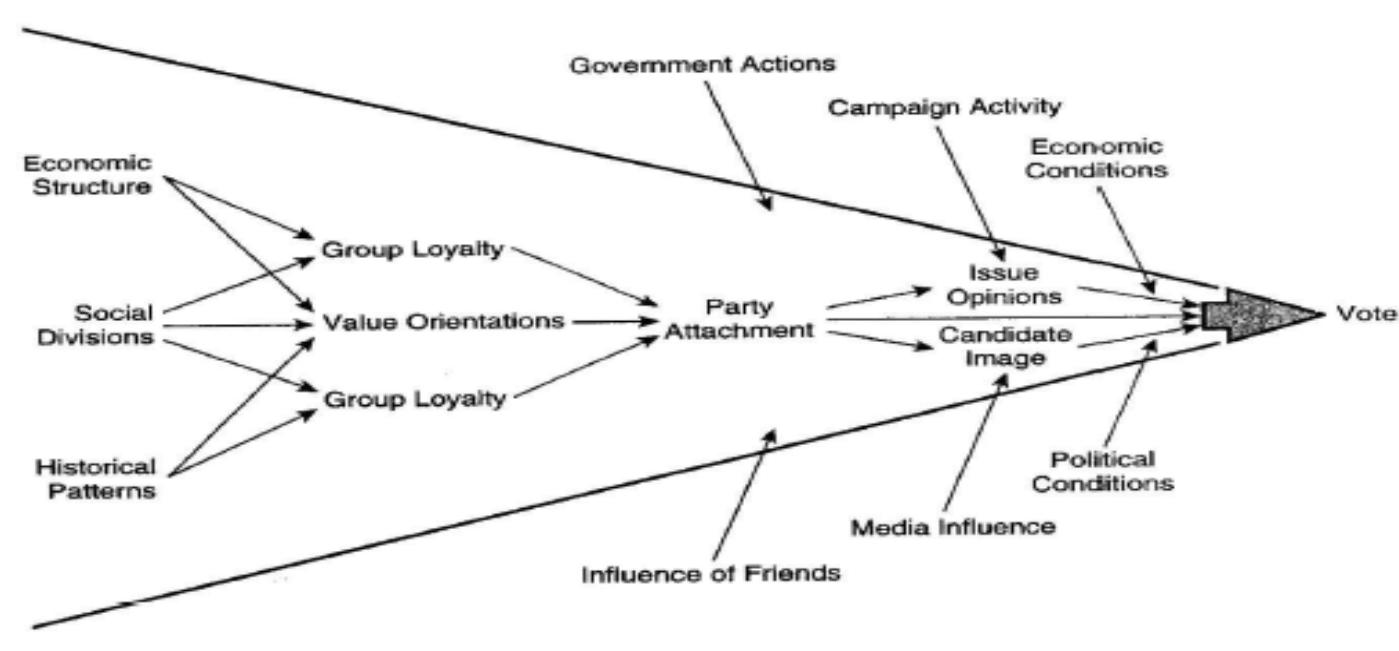


memengaruhi keputusan pemilu melalui trias determinant: identifikasi partai (Party ID), orientasi kandidat dan orientasi isu. Penggambaran ini dapat dilihat dari penjelasan Dalton bahwa proses perilaku memilih model psikologis seperti sebuah saringan dalam corong kausalitas (funnel causality) seperti dalam gambar 1 (Dalton, 2002: 173).

Pada bagian corong yang lebar adalah kondisi sosial ekonomi yang menghasilkan pembagian politik yang luas dari masyarakat: struktur ekonomi, perpecahan sosial seperti ras atau agama, dan keberpihakan sejarah. Faktor-faktor ini memengaruhi struktur dalam sistem kepartaian, tetapi tidak memengaruhi keputusan suara pemilih. Ketika bergerak melalui saluran kausal, kondisi sosial ekonomi memengaruhi loyalitas kelompok dan orientasi nilai dasar. Misalnya, kondisi ekonomi mungkin mengikat individu kepada kelas sosial, atau identitas daerah dapat membentuk reaksi terhadap kesenjangan sosial dan politik. Dengan demikian, kondisi sosial dijabarkan ke dalam sikap yang secara langsung dapat memengaruhi perilaku politik individu. Pada corong kausalitas yang menyempit merupakan sebuah loyalitas kelompok dan prioritas nilai yang terhubung ke sikap politik yang lebih eksplisit. Ujung lebar dari corong mewakili kondisi sosial yang luas, menunjukkan bahwa struktur sosial jauh dari keputusan pemilih yang sebenarnya. Ketika bergerak melalui corong, perhatian bergeser ke faktor-faktor yang secara eksplisit politis, melibatkan keyakinan dan pengetahuan individu. Karakteristik sosial itu dilihat sebagai aspek penting dari proses pemungutan suara, tetapi pengaruhutama adalah dalam membentuk orientasi politik. Sebagian besar dampak langsung dari karakteristik sosial pada pemilih dimediasi oleh disposisi sikap. Sikap, pada gilirannya, tergantung pada loyalitas kelompok dan orientasi nilai individu, serta rangsangan eksternal seperti teman-teman, media, kebijakan pemerintah, dan kegiatan kampanye (Dalton, 2002:174).
Model ini menjelaskan keputusan suara individu didasarkan dalam tiga sikap: partisanship (keberpihakan), pendapat terhadap isu, dan citra kandidat. Keyakinan inilah yang paling dekat pada keputusan suara dan karena itu memiliki dampak langsung dan sangat kuat terhadap perilaku memilih (Dalton, 2002: 173). Partisanship sebagai salah satu konsep dalam pendekatan psikologis adalah kedekatan psikologis yang merupakan hubungan yang stabil dan bertahan lama dengan partai politik. Situasi di mana individu memilih kelompok rujukan, walaupun mereka tidak menyatu didalamnya dan mulai bertindak sesuai dengan apa yang mereka anggap sebagai aturan kelompok tersebut. Identifikasi dengan partai disebut dengan istilah party ID, yakni perasaan seseorang bahwa partai tertentu adalah identitas politiknya, bahwa ia mengidentikan diri sebagai orang partai tertentu, atau bahwa ia merasa dekat dengan partai politik tertentu.

Pendekatan perilaku memilihyang terakhir yakni model rational choice atau pilihan rasional. Rational choice adalah sebuah pendekatan perilaku memilih yang merupakan kritik terhadap dua model pendekatan yang sudah ada yaitu pendekatan sosiologis dan psikologis. Ada kegelisahan ilmuwan melihat perubahanperubahan perilaku memilih yang tidak bisa dijelaskan oleh dua pendekatan tersebut. Latar belakang teoritis untuk penjelasan pendekatan ini berangkat dari teori ekonomi (Mujani et. al, 2012; Bartels, 2012). Model ini merupakan upaya untuk menjelaskan perilaku memilih yang berhubungan dengan parameter ekonomi-politik. Premisnya sederhana, jika asumsi pilihan rasional mampu menjelaskan pasar, maka hal ini juga dapat menjelaskan fungsi politik. Operasi model ini didasarkan bahwa semua keputusan yang telah dibuat oleh pemilih bersifat rasional, yakni dipandu oleh kepentingan diri sendiri dan diberlakukan sesuai dengan prinsip maksimalisasi manfaat. Pilihan politik pemilih yang rasional senantiasa berorientasi kepada hasil yang dicapai oleh 
partai atau kandidat tertentu dalam politik, baik hasil yang dipersepsikan maupun yang diantisipasi (Roth, 2008: 49).

Berdasarkan keseluruhan uraian diatas, ketiga model tersebut tidak harus bertentangan. Sebaliknya, ketiganya mempunyai pengaruh relatif terhadap pilihan politik (Mujani et al., 2012: 34). Singkatnya, dalam studi perilaku memilih, sejatinya dilihat dalam pendekatan probabilistik bukan deterministik, karena semua faktor dapat berpengaruh. Jadi, yang dilihat pada sisi proporsionalitas faktor, seberapa besar faktor yang dominan dan mampu menjelaskan pilihan politik dengan lebih baik.

\section{Pemilihan Gubernur dan Geopolitik Sulawesi Selatan}

Pemilihan Gubernur dan Wakil Gubernur (Pilgub) Sulawesi Selatan (Sulsel) yang digelar pada 22 Januari 2013 menyisakan 3 pasangan kandidat: Ilham Arif Sirajuddin - Aziz Qahhar Mudzakkar (IA), Syahrul Yasin Limpo - Agus Arifin Nu'mang (Sayang), dan Andi Rudiyanto Asapa - Andi Nawir Pasinringi (Garuda-Na). Dukungan kepada ketiga pasangan kandidat yang bertarung tersebut masing-masing: IA didukung 34,46 persen suara parpol, Sayang dengan 49 persen, dan Garuda-Na sebesar 16,54 persen (lihat tabel 1). ${ }^{1}$

Pasangan nomor urut satu, Ilham Arief Siradjuddin dan Azis Qahhar Mudzakkar diusung Partai Demokrat, Partai Keadilan Sejahtera (PKS), Partai Hati Nurani Rakyat (Hanura), Partai Bulan Bintang (PBB), Partai Bintang Reformasi (PBR), Partai Karya Peduli Bangsa (PKPB), Partai Kebangkitan Bangsa (PKB), Partai Patriot, Partai Karya Perjuangan (Pakar Pangan), Partai Penegak Demokrat Indonesia (PPDI) dan Partai Nasional Indonesia Marhaenisme (PNI Marhaenisme). Sementara itu, Syahrul Yasin Limpo dan Agus Arifin Nu'mang diusung Partai Golkar, Partai

${ }^{1}$ KPUD Sulawesi Selatan.
Amanat Nasional (PAN), Partai Demokrasi Indonesia Perjuangan (PDIP), Partai Demokrasi Kebangsaan (PDK), Partai Keadilan dan Persatuan Indonesia (PKPI), Partai Persatuan Pembangunan (PPP), Partai Kebangkitan Nasional Ulama (PKNU), dan Partai Damai Sejahtera (PDS). Pasangan nomor urut terakhir, Andi Rudiyanto Asapa dan Andi Nawir Pasinringi diusung Partai Gerakan Indonesia Raya (Gerindra), Partai Pemuda Indonesia (PPI), Partai Kedaulatan, Partai Nasional Benteng Kerakyatan Indonesia (PNBKI), Partai Indonesia Sejahtera (PIS), Partai Merdeka, Partai Pengusaha dan Pekerja Indonesia (PPPI), Partai Persatuan Nahdlatul Ummah Indonesia (PPNUI), Partai Matahari Bangsa (PMB), Partai Kasih Demokrasi Indonesia (PKDI), Partai Perjuangan Indonesia Baru (PPIB), Partai Republika Nusantara (Republikan), Partai Peduli Rakyat Nasional (PPRN), Partai Persatuan Daerah (PPD), Partai Pelopor, Partai Demokrasi Pembaruan (PDP), Partai Nasional Republik (Partai Nasrep), Partai Buruh, Partai Barisan Nasional (Partai Barnas), dan Partai Pelopor.

Sebagai pemenang, Syahrul Yasin Limpo dan Agus Arifin Nu'mang memperoleh suara terbesar yakni 2.251.407 suara atau 52,42 persen. Pasangan ini merupakan petahana (incumbent), dimana pada Pilgub sebelumnya juga berpasangan. Syahrul Yasin Limpo lahir di Ngawing, Makassar pada tanggal 15 Maret 1955. Sebelum menjabat sebagai Gubernur, Syahrul Yasin Limpo pernah menjabat sebagai Bupati di Kabupaten Gowa selama dua periode. Syahrul Yasin Limpo kemudian menjabat Wakil Gubernur selama satu periode mendampingi Amin Syam, sebelum akhirnya memenangkan pertarungan bersama Agus Arifin Nu'mang dalam Pilgub Sulsel di tahun 2007. Gubernur yang terkenal dengan tagline "Sayang" (singkatan dari Syahrul Yasin Limpo-Agus Arifin Nu'mang) dikenal di masyarakat dengan program pendidikan dan kesehatan gratis. Program tersebut dianggap sebagai "sesuatu yang baru" bagi masyarakat 
Tabel 1.

Koalisi Partai Pengusung Pasangan Calon Pilgub Sulawesi Selatan 2013

\begin{tabular}{llll}
\hline \multicolumn{1}{c}{ IA } & \multicolumn{1}{c}{ Sayang } & \multicolumn{1}{c}{ Garuda-Na } \\
\hline & Partai Demokrat, PKS, & Partai Golkar, & Partai Gerindra, PPI, Partai \\
& Partai Hanura, PBB, & Kedaulatan, PNBKI, PIS, Partai \\
Partai Politik & PBR, PKPB, PKB, & PAN, PDIP, & Merdeka, PPPI, PPNUI, PMB, PKDI, \\
& Partai Patriot, Pakar & PDK, PKPI, & PPIB, Partai Republikan, PPRN, PPD, \\
& Pangan, PPDI, dan & PPP, PKNU, & PDP, Partai Nasrep, Partai Buruh, \\
& PNI Marhaenisme & dan PDS & Partai Barnas, dan Partai Pelopor \\
Jumlah Partai & 11 & 8 & 19 \\
Persentase & 34,46 & 49 & 16,54 \\
\hline
\end{tabular}

Sumber: KPUD Sulawesi Selatan

pada tahun 2007, sehingga diyakini sebagai gebrakan dan menjanjikan kesejahteraan di Sulawesi Selatan. Pada Pilgub 2013, pendidikan dan kesehatan gratis masih menjadi "jualan politik" pasangan ini, dengan menunjukkan keberhasilan-keberhasilan dari program yang mereka kerjakan. Dengan latar belakang etnis Makassar, Syahrul Yasin Limpo diyakini memiliki lumbung suara didaerah yang mayoritas dihuni oleh etnis Makassar, seperti daerah selatan. Syahrul Yasin Limpo pada saat ini juga merupakan Ketua DPD Partai Golkar Sulawesi Selatan, sedangkan Agus Arifin Nu'mang, pasangan wakil gubernur adalah mantan Ketua DPRD Sulawesi Selatan 2004-2007. Agus Arifin Nu'mang berasal dari Kabupaten Sidrap yang merupakan kawasan Ajatappareng dengan mayoritas etnis Bugis. Sebelum aktif dalam politik sebagai kader Partai Golkar, Agus Arifin Nu'mang berprofesi sebagai dosen di salah satu Universitas di Makassar.

Perolehan suara kedua ditempati pasangan Ilham Arif Sirajuddin - Aziz Qahhar Mudzakkar yang mengumpulkan 1.785 .580 suara atau 41,57 persen. Ilham Arif Sirajuddin sebagai calon gubernur merupakan putra Bugis, dimana orang tuanya berasal dari Kabupaten Bone. Tercatat sebagai Walikota Makassar dua periode sejak tahun 2004. Ilham Arif Sirajuddin adalah Ketua DPD Partai Demokrat Sulawesi Selatan 2010-2015. Namun sebelumnya, Ilham Arif Sirajuddin aktif sebagai fungsionaris Partai Golkar sebagai Ketua DPD Partai Golkar Sulawesi Selatan. Ilham Arif Sirajuddin pun beralih ke Partai Demokrat setelah kalah bersaing dengan Syahrul Yasin Limpo dalam perebutan ketua DPD Partai Golkar Sulawesi Selatan. Sementara itu, calon wakil gubernur pasangan IA, Aziz Qahhar Mudzakkar merupakan putra Qahhar Mudzakkar (Pemimpin DI/TII) yang berasal dari Kabupaten Luwu dengan latar belakang etnis Luwu. Terpilih dalam dua periode sebagai Anggota DPD RI sejak tahun 2004 sampai sekarang. Sebelumnya, Aziz Qahhar Mudzakkar juga pernah mencalonkan diri sebagai calon gubernur pada Pilgub tahun 2007 yang telah dimenangkan oleh Sayang. Nama Aziz Qahhar Mudzakkar sangat dikenal di masyarakat Luwu Raya karena kharisma orang tuanya. Popularitas tersebut menjadikannya di urutan pertama dalam perolehan suara anggota DPD RI tahun 2009 lalu.

Pasangan dengan perolehan suara terkecil yakni Andi Rudiyanto Asapa - Andi Nawir Pasinringi yang memperoleh 257.973 suara atau 6,01 persen. Calon gubernur pasangan Garuda-Na, Andi Rudiyanto Asapa berasal dari Kabupaten Sinjai, sekaligus menjabat Bupati dua periode di kabupaten tersebut sejak tahun 2003. Selain itu, Andi Rudiyanto Asapa juga menjabat Ketua DPD Partai Gerindra Sulawesi Selatan. Sementara itu, Andi Nawir Pasinringi, calon wakil gubernur yang berasal 
dari Kabupaten Pinrang, dimana Andi Nawir Pasinringi juga pernah menjabat sebagai Bupati Pinrang selama dua periode pada tahun 19992009. Selain itu, Andi Nawir Pasinringi pernah menjabat sebagai Ketua DPD Partai Demokrat Sulawesi Selatan sebelum dilengserkan oleh Ilham Arif Sirajuddin. Akhirnya, Andi Nawir Pasinringi keluar dari partai belambang segitiga tersebut. Dilihat dari nama pasangan calon Garuda-Na sudah jelas bahwa kedua kandidat tersebut berasal dari etnis Bugis.

Berkaitan dengan geopolitik, pada umumnya konsep analisis geopolitik berkaitan dengan peta etnografi suatu kawasan, seperti daerah, etnis, budaya, bahasa serta agama sebagai relevansi politik. Pada uraian selanjutnya, artikel ini menguraikan beberapa aspek geopolitik yang memengaruhi pola dan komposisi para kandidat dalam Pilgub Sulawesi Selatan tahun 2013. Secara geopolitik, Sulawesi Selatan dapat dibagi kedalam lima kawasan: (1) Bosowasi, terdiri atas Kabupaten Bone, Soppeng, Wajo, dan Sinjai; (2) Luwu Raya terdiri atas Kabupaten Luwu, Luwu Utara, Luwu Timur, dan Kota Palopo; (3) Ajatappareng terdiri atas Kabupaten Barru, Sidrap, Pinrang, Enrekang, dan Kota Parepare; (4) Selatan-Selatan terdiri atas Kota Makassar,

Tabel 2.

Perolehan Suara Pemilihan Gubernur dan Wakil Gubernur Sulawesi Selatan 2013

\begin{tabular}{lccc}
\hline \multicolumn{1}{c}{ Kabupaten/Kota } & $\begin{array}{c}\text { Ilham Arif Sirajuddin } \\
\text { - Abd. Azis Qahhar } \\
\text { Mudzakkar }\end{array}$ & $\begin{array}{c}\text { Syahrul Yasin Limpo - } \\
\text { Agus Arifin Nu'mang }\end{array}$ & $\begin{array}{c}\text { Andi Rudiyanto } \\
\text { Asap - Andi Nawir } \\
\text { Pasinringi }\end{array}$ \\
\hline Bantaeng & 37.210 & 47.101 & 4.747 \\
Barru & 35.149 & 59.296 & 1.302 \\
Bone & 244.526 & 129.234 & 30.258 \\
Bulukumba & 78.497 & 106.233 & 14.616 \\
Enrekang & 57.769 & 42.698 & 1.529 \\
Gowa & 66.542 & 312.199 & 8.603 \\
Jeneponto & 44.562 & 131.459 & 7.631 \\
Kota Parepare & 26.466 & 37.235 & 2.334 \\
Luwu & 120.610 & 59.881 & 3.505 \\
Luwu Timur & 49.002 & 75.781 & 1.587 \\
Luwu Utara & 74.728 & 70.074 & 4.360 \\
Makassar & 313.056 & 285.418 & 29.116 \\
Maros & 86.907 & 70.806 & 6.294 \\
Palopo & 53.082 & 25.982 & 2.981 \\
Pangkep & 85.722 & 71.639 & 5.341 \\
Pinrang & 69.626 & 84.187 & 31.215 \\
Selayar & 20.464 & 45.324 & 2.672 \\
Sidenreng Rappang & 59.983 & 101.291 & 2.746 \\
Sinjai & 35.602 & 20.533 & 71.341 \\
Soppeng & 52.084 & 75.929 & 3.942 \\
Takalar & 37.763 & 109.586 & 2.930 \\
Tana Toraja & 17.584 & 90.760 & 4.452 \\
Toraja Utara & 10.796 & 94.634 & 8.536 \\
Wajo & 108.849 & 104.127 & 5.935 \\
Jumlah & 1.785 .580 & 2.251 .407 & 6.01 \\
Persentase & 41,57 & 52,42 & \\
\hline & & & \\
\hline
\end{tabular}

Sumber: KPUD Sulawesi Selatan 
Kabupaten Gowa, Takalar, Jeneponto dan Bantaeng; dan (5) Toraja terdiri atas Kabupaten Toraja dan Toraja Utara.

Daerah-daerah yang berada dalam kawasan Bosowasi dan Ajatappareng secara kultural memiliki identitas yang sama sebagai komunitas etnis Bugis, sedangkan kawasan Selatan-Selatan disatukan oleh etnis Makassar. Adapun Luwu Raya sangat heterogen, kawasan ini sangat beragam baik dari segi etnis, budaya, bahasa maupun agama. Hal ini dikarenakan Kawasan Luwu Raya merupakan destinasi transmigrasi dari Jawa dan Bali, warisan Orde Baru. Namun, mayoritas masyarakat yang mendiami kawasan ini adalah etnis Luwu. Sementara itu, kawasan Toraja mayoritas dihuni oleh etnis Toraja. Berbeda dengan kawasan lainnya yang mayoritas Islam, kawasan Toraja mayoritas beragama Kristen dan Katolik.

Apabila melihat komposisi pasangan calon Gubernur dan Wakil Gubernur pada Pilgub 2013 beberapa waktu yang lalu, sulit dipungkiri bahwa faktor geopolitik ikut berpengaruh terhadap basis kalkulasi pasangan calon yang berkompetisi. Pasangan Ilham Arief Sirajuddin dan Aziz Qahhar Muzakkar secara simbolik merupakan perpaduan antara basis representasi geopolitik Bosowasi dan Luwu Raya. Ilham Arief Sirajuddin merupakan putra kelahiran Bone, sedangkan Aziz Qahhar Muzakkar berasal dari Luwu Raya. Sementara itu, tafsiran geopolitik serupa juga berlaku terhadap pasangan petahana (incumbent) Syahrul Yasin Limpo dan Agus Arifin Nu'mang. Jika Syahrul Yasin Limpo mewakili simbol politik daerah Selatan-Selatan karena latar belakang etnis Makassar, maka wakilnya, Agus Arifin Numang representasi wilayah Ajatappareng, dimana Kabupaten Sidrap adalah kampung halamannya. Begitu halnya pasangan Garuda$\mathrm{Na}$, Andi Rudiyanto Asapa dan Andi Nawir Pasinringi. Andi Rudiyanto Asapa merupakan representasi geopolitik Bosowasi, dimana Andi Rudiyanto Asapa merupakan Bupati aktif di kabupaten Sinjai, sedangkan pasangannya,
Andi Nawir Pasinringi berasal dari Pinrang, wilayah Ajatappareng.

Beberapa ilmuwan politik bahkan mengatakan faktor geopolitik menjadi penentu kemenangan calon di Pilgub 2013. Pasangan Sayang akan berkuasa di Selatan-Selatan, mulai dari Gowa hingga Bulukumba, IA akan menguasai Bosowasi dan Luwu Raya, sedangkan Garuda'Na akan mendulang suara di Sinjai dan Ajatappareng.

"Sulit dipungkiri geopolitik ikut memengaruhi pertemuan paket calon. Terbukti keputusan Ilham-Azis tidak terlepas dari tafsir geopolitik, meskipun batasan geopolitik masih bisa diperdebatkan. Namun, perpaduan Ilham-Aziz dianggap sebagai simbol basis representasi Bosowa dan Luwu Raya" (DR. Muh Firdaus, dosen Politik UIN Alauddin). ${ }^{2}$

"...faktor geopolitik tidak bisa
dipungkiri menjadi basis kandidat. ...
variabel etnis dan kultural menjadi
wilayah pertarungan semua kandidat"
(Muh. Aris, Direktur Eksekutif Insert
Institute)."

Pertanyaannya kemudian, walaupun kandidat menggunakan analisis geopolitik sebagai strategi untuk memenangkan jabatan Gubernur dan Wakil Gubernur Sulawesi Selatan untuk periode 2013-2018, kenyataan membuktikan dugaan tersebut tidak tepat. Pasangan Sayang mampu untuk memenangkan suara dalam peta geopolitik lawan. Pada kawasan Luwu Raya yang merupakan basis IA, Sayang mampu menang di Kabupaten Luwu Timur. Dengan total 126.370 suara sah, Sayang memperoleh 75.781 suara (59, 97 persen), IA dengan 49.002 suara $(38,78$ persen), dan Garuda-Na dengan 1.587 suara (1,25 persen). Begitu halnya di Kabupaten Pinrang yang secara geopolitik adalah kawasan Ajatappareng, yang merupakan basis Garuda-

\footnotetext{
${ }^{2}$ www.rakyatsulsel.com.

${ }^{3}$ www.luwuraya.net.
} 
$\mathrm{Na}$, dimana calon wakil gubernur Andi Nawir Pasinringi berasal dari kabupaten tersebut dan pernah menjabat Bupati Pinrang dua periode. Kali ini, dengan total 185.028 suara sah, Sayang memperoleh 84.187 suara (45,50 persen), diikuti IA dengan 69.626 (37,63 persen), sedangkan Garuda-Na hanya mampu meraih 31.215 suara (16,87 persen).

Singkatnya, keseluruhan pasangan calon apabila dianalisis dengan profil sosiologis merupakan representasi geopolitik Sulawesi Selatan. Pasangan Sayang merupakan representasi Bugis-Makassar dengan pembagian kawasan Selatan-Selatan dan Ajatappareng, pasangan IA merupakan komposisi etnis BugisLuwu dengan representasi Ilham Arif Sirajuddin yang berasal dari kawasan Bosowasi dan Aziz Qahhar Mudzakkar yang berasal dari kawasan Luwu Raya, dan terakhir pasangan Garuda-Na, Andi Rudiyanto Asapa berasal dari kawasan Bosowasi sedangkan Andi Nawir Pasinringi berasal dari kawasan Ajatappareng. Akan tetapi, kenyataan pemilu berkata lain, dimana faktor geopolitik tidak secara signifikan mempengaruhi pilihan suara di dua kabupaten tersebut. Dalam perbandingan berikut, Kabupaten Luwu Timur dan Kabupaten Pinrang menjadi pusat analisis. Alasan memilih dua kabupaten ini yakni Kabupaten Luwu Timur dipilih karena sebagai basis geopolitik pasangan IA, sedangkan Kabupaten Pinrang dipilih karena merupakan basis geopolitik Garuda-Na. Di dua kabupaten tersebut pasangan Sayang berhasil menang dengan memperoleh suara terbanyak.

\section{Kabupaten Luwu Timur}

Kabupaten Luwu Timur merupakan kabupaten paling timur di Provinsi Sulawesi Selatan yang berbatasan langsung dengan Provinsi Sulawesi Tengah dan Provinsi Sulawesi Tenggara. Luwu Timur merupakan kabupaten yang saat ini tingkat perekonomiannya terbaik di Sulawesi Selatan, sejak dimekarkan dari Luwu Utara tahun 2003. Mayoritas etnis yang mendiami daerah ini adalah etnis Luwu.
Aziz Qahhar Mudzakkar sebagai salah satu calon wakil gubernur diidentikkan dengan kabupaten Luwu Timur. Dengan latar belakang etnis Luwu dan pengaruh kharisma orang tuanya, Aziz Qahhar Mudzakkar sangat dikenal di daerah ini. Rekam jejak perjuangan Qahhar Mudzakkar, orang tua Aziz Qahhar Mudzakkar, diyakini oleh kebanyakan masyarakat menjadi penyebab adanya faktor kedekatan emosional yang kuat antara masyarakat Luwu Timur dengan calon wakil gubernur dari pasangan IA tersebut (Irfan Yahya, wawancara pribadi 11 September 2013). Pada Pemilu DPD 2009, Aziz Qahhar Mudzakkar bahkan memperoleh 35,67 persen dari keseluruhan suara sah di kabupaten ini.

Namun, pada Pilgub 2013 yang telah berlalu pada awal tahun, menunjukkan kedekatan emosional antara pemilih dan calon kandidat tidak begitu dominan dalam menentukan perilaku memilih warga di Luwu Timur. Walaupun pasangan IA dengan Aziz Qahhar Mudzakkar telah mengakar dengan kuat pada wilayah kabupaten ini dengan adanya ikatan etnis dan kedaerahan, pasangan Sayang mampu meraup suara sebesar 59,97 persen. Angka ini cukup fantastis, mengingat bahwa kabupaten Luwu Timur merupakan wilayah Luwu Raya yang diklaim oleh banyak kalangan sebagai basis geopolitik pasangan IA (Muhammad Ayyub, wawancara pribadi 12 Agustus 2013). Kenyataannya, pasangan IA hanya mampu memperoleh 38,78 persen suara.

Tabel 3.

\begin{tabular}{|c|c|c|c|}
\hline \multicolumn{4}{|c|}{$\begin{array}{l}\text { Perolehan Suara Koalisi Partai } \\
\text { Berdasarkan Pemilu Legislatif DPRD } \\
\text { Provinsi Tahun } 2009 \text { di Luwu Timur }\end{array}$} \\
\hline & IA & Sayang & Garuda-Na \\
\hline amlah & 34.483 & 60.831 & 16.332 \\
\hline Persentase & 30,88 & 54,47 & 14,62 \\
\hline buara Sah & 111.675 & & \\
\hline
\end{tabular}

Sumber: KPUD Luwu Timur 
Tabel 4.

Rekapitulasi Perolehan Suara Pasangan Calon Pilgub 2013 di Luwu Timur

\begin{tabular}{lccc}
\hline & IA & Sayang & $\begin{array}{c}\text { Garuda- } \\
\mathrm{Na}\end{array}$ \\
\hline Jumlah & 49.002 & 75.781 & 1.567 \\
Persentase & 38,78 & 59,97 & 1,25 \\
\hline Total Suara Sah & 126.370 & & \\
\hline
\end{tabular}

Sumber: KPUD Luwu Timur

Dalam analisis perolehan suara berdasarkan Pemilu 2009 dan Pilgub 2013, disimpulkan bahwa warga yang memilih partai yang tergabung dalam koalisi partai pendukung pasangan Sayang juga memilih pasangan Sayang dalam Pilgub 2013. Hal ini menandakan bahwa suara yang diberikan untuk kandidat berasal dari partai yang sama (straight-ticket voting). Pemilih cenderung mengidentikkan pilihan pada kandidat dalam Pilgub dengan pilihan partai politiknya pada pemilu sebelumnya. Selain itu, sepanjang sejarah partai penguasa di kabupaten ini, partai Golkar selalu berhasil memenangkan Bupati yang diusungnya. Kedekatan pemilih dengan partai Golkar sangat memengaruhi relevansi keterpilihan kandidat karena sebagian besar daerah di Kabupaten Luwu Timur adalah daerah transmigrasi Orde Baru - masyarakat daerah transmigran dikenal dekat dengan Golkar. Bagi sebagian masyarakat transmigran, Golkar adalah salah satu bagian dari hidup mereka (Karyadi, wawancara pribadi, 7 Agustus 2013). Hal inilah yang menandakan kekuatan sosiologis pasangan IA tidak begitu signifikan memengaruhi pilihan politik masyarakat. Persentase pasangan Sayang berdasarkan kedekatan partai (jumlah koalisi partai) terbukti mampu memenangkan pasangan ini di Kabupaten Luwu Timur.

Pada pemilu DPRD provinsi tahun 2009, jika jumlah suara seluruh partai koalisi pengusung

\section{Grafik 1.}

Split-Ticket Voting di Kabupaten Luwu Timur berdasarkan Persentase Perolehan Suara Koalisi Partai di Pemilu DPRD Provinsi 2009 dan Persentase Suara Pasangan Calon di Pilgub 2013

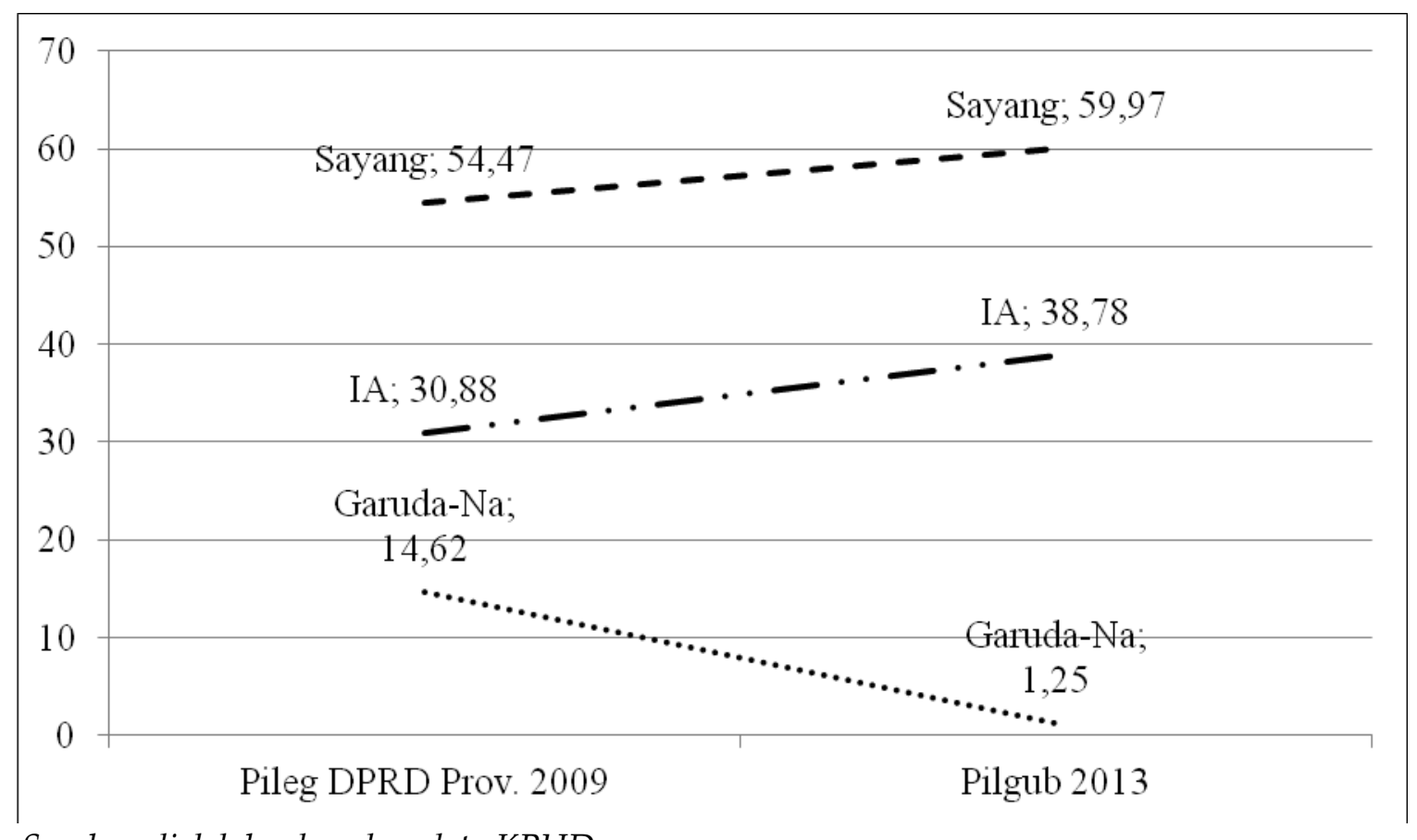

Sumber: diolah berdasarkan data KPUD 
pasangan Sayang digabungkan, maka diperoleh 54,47 persen dari total suara sah (lihat Tabel 3). Apabila persentase perolehan suara partai koalisi tersebut kemudian di hubungkan dengan persentase perolehan suara pasangan Sayang di Luwu Timur yakni sebesar 59,97 persen (lihat tabel 3), maka dapat disimpulkan sebagai splitticket voting (lihat grafik 1). Kesimpulannya, seluruh warga yang memilih dalam partai koalisi, juga memilih kandidat pasangan Sayang. Sekitar 5,5 persen ${ }^{4}$ pemilih di Luwu Timur dikategorisasikan sebagai split-ticket voting, kemungkinan besar berasal dari partai yang berbeda yang kemudian mengalihkan suaranya kepada pasangan Sayang. ${ }^{5}$ Sementara itu, untuk pasangan IA terdapat split-ticket voting sebesar 7,9 persen, sedangkan pasangan Garuda-Na sebesar 13,37 persen.

\section{Kabupaten Pinrang}

Pinrang merupakan kabupaten yang terletak pada bagian tengah Provinsi Sulawesi Selatan. Mayoritas masyarakat Pinrang bergerak dalam bidang agraris dalam menunjang kehidupan perekonomiannya, dimana daerah ini merupakan salah satu daerah pemasok beras terbesar di Indonesia. Secara sosiologis Kabupaten Pinrang dihuni oleh mayoritas etnis Bugis yang mendiami 12 kecamatan dan 104 desa/kelurahan.

Salah satu calon wakil gubernur berasal dari kabupaten ini, Andi Nawir Pasinringi yang merupakan pasangan dari kandidat GarudaNa. Pengalaman puluhan tahun sebagai birokrat di Kabupaten Pinrang menjadikan Andi Nawir Pasinringi sangat dikenal di masyarakat. Andi Nawir Pasinringi tercatat pernah menduduki sejumlah jabatan penting

\footnotetext{
4 Persentase suara Sayang di Pilgub dikurangi persentase suara koalisi partai di Pileg DPRD provinsi 2009.

5 Split-ticket voting adalah pemilih memilih calon dari partai politik yang berbeda, misalnya pemilih dalam pemilu legislatif memilih calon dari partai A tetapi pada pemilu eksekutif (presiden/gubernur) memilih calon dari partai B.
}

sejak tahun 1976, diantaranya: Kepala Desa Paria; dua kali menjabat sebagai Camat di Cempa dan Watang Sawitto (1987-1989); Kepala Dinas Kebersihan Kabupaten Pinrang; Asisten Administrasi Pembangunan Setda Kabupaten Pinrang dan Kepala Dinas Pendapatan Daerah Kabupaten Pinrang. Puncaknya, ketika Andi Nawir Pasinringi terpilih dalam dua periode sebagai Bupati Pinrang (1999-2009). Gelar sebagai bangsawan Bugis juga menjadi faktor penentu, tokoh ini dikenal dengan baik di masyarakat Pinrang.

Nampaknya, sejumlah pengalaman tersebut menjadikan Andi Nawir Pasinringi sangat percaya diri maju dalam Pilgub Sulawesi Selatan tahun 2013, mendampingi Andi Rudiyanto Asapa. Dalam sebuah media cetak harian, Andi Nawir Pasinringi dengan sangat yakin berkata:

\begin{abstract}
"Saya tidak maju kalau tidak optimis. Saya tidak berharap pada Demokrat. Saya kan punya keluarga banyak. Pokoknya yang begini-begini, orang tidak lihat partai lagi. Saya tidak akan menggembosi siapapun." Kemudian dia melanjutkan "Sekecil apapun saya, pasti ada suara. Tidak mungkin tidak. Dan saya optimis, di Pinrang saya dapat 80 persen (200 ribu suara.red). Bodoh itu orang Pinrang kalau tidak pilih saya." 6
\end{abstract}

Harapan yang begitu besar dari Andi Nawir Pasinringi, ternyata berbeda dengan das sein. Pasangan Garuda-Na kalah telak dalam perolehan suara di Kabupaten Pinrang. Seperti halnya dalam kasus yang terjadi di Luwu Timur, walaupun kandidat telah mengakar dengan kuat di Kabupaten Pinrang, ternyata tidak cukup untuk memenangkan suara. Garuda-Na hanya mampu meraup 16,87 persen suara, sementara suara terbesar diperoleh Sayang dengan 45,50 persen disusul pasangan IA dengan 37,63 persen (lihat Tabel 5).

\footnotetext{
6 www.suwadiidrisamir.com.
} 
Tabel 5.

Perolehan Suara Pasangan Calon Pilgub 2013 di Kabupaten Pinrang

\begin{tabular}{lccc}
\hline & IA & Sayang & Garuda-Na \\
\hline Jumlah & 69.626 & 84.187 & 31.215 \\
Persentase & 37,63 & 45,50 & 16,87 \\
\hline Suara Sah & 185.028 & & \\
\hline
\end{tabular}

Sumber: KPUD Pinrang

Tabel 6.

Perolehan Suara Koalisi Partai

Berdasarkan Pemilu Legislatif DPRD

Provinsi Tahun 2009 di Kabupaten

Pinrang

\begin{tabular}{lccc}
\hline & IA & Sayang & Garuda-NA \\
\hline Jumlah & 81.594 & 72.370 & 21.915 \\
Persentase & 46,18 & 40,96 & 12,40 \\
\hline Suara Sah & 176.687 & & \\
\hline
\end{tabular}

Sumber: KPUD Pinrang

Apabila dianalisis berdasarkan statistik perolehan suara pada dua rangkaian pemilihan yakni Pileg DPRD Provinsi Sulawesi Selatan tahun 2009 dan Pilgub tahun 2013, maka terlihat bahwa selisih persentase pemilih partai koalisi pasangan Garuda-Na di Pemilu 2009 tidak berbeda jauh dengan persentase pemilih Garuda-Na di Pilgub 2013, dimana terdapat split-ticket voting sebesar 4,43 persen (lihat grafik 2). Besaran split-ticket voting juga hampir sama persis dengan persentase pemilih Sayang yakni 4,54 persen, sedangkan untuk pasangan IA, split-ticket voting sebesar 8,55 persen.

Kemenangan Sayang di Kabupaten Pinrang juga menegaskan kekuatan sosiologis dari kandidat tidak cukup berpengaruh untuk menentukan pilihan politik. Dua periode memimpin Kabupaten Pinrang, calon wakil gubernur pasangan Garuda-Na tidak mampu memengaruhi perilaku memilih masyarakat Pinrang. Split-ticket voting yang tidak lebih besar dari 5 persen, menandakan bahwa pemilih yang memilih koalisi partai pengusung Garuda-Na yang berjumlah 19 partai politik juga memilih pasangan ini. Begitu halnya dengan statistik

\section{Grafik 2.}

Split-Ticket Voting di Kabupaten Pinrang berdasarkan Persentase Perolehan Suara Koalisi Partai di Pemilu DPRD Provinsi 2009 dan Persentase Suara Pasangan Calon di Pilgub 2013

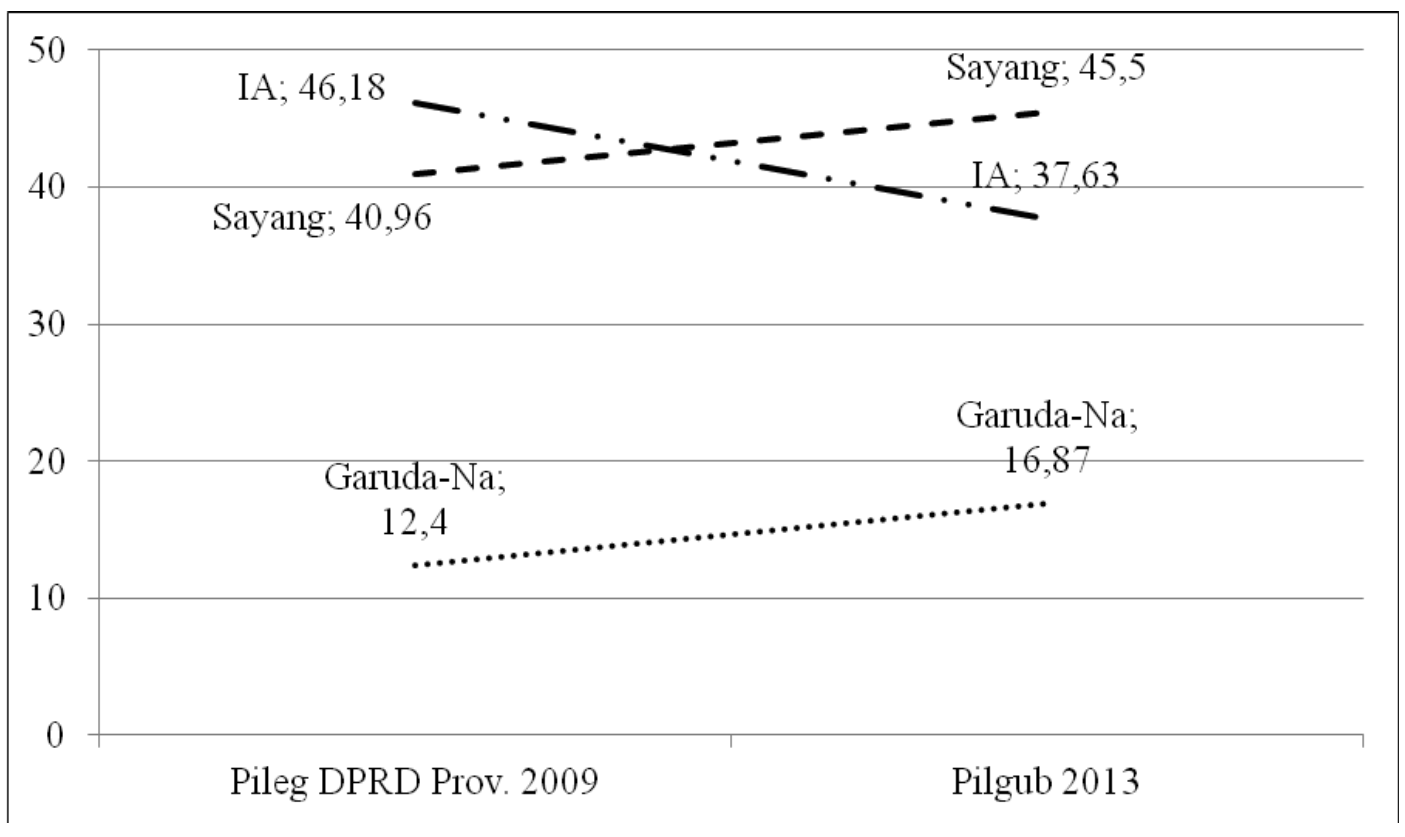

Sumber: diolah berdasarkan data KPUD 
antara pemilihkoalisi partai dan pemilih pasangan Sayang yang besaran persentasenya juga tidak lebih dari 5 persen. Selain itu, keanggotaan psikologis dalam partai Golkar yang merupakan hasil pengaruhjangka panjang sejakera OrdeBaru juga memiliki pengaruh signifikan. Sejarah partai Golkar di daerah ini dan di Sulawesi Selatan pada umumnya erat hubungannya dengan memorimemori masa lalu yang telah membangun ikatan psikologis yang terbentuk dalam diri individu. Partai Golkar dianggap memang lebih baik dalam membentuk kelembagaan partai dibandingkan sebagian besar partai lain di Indonesia (Tomsa, 2008: 180). Kesimpulannya, hampir dipastikan bahwa pemilih partai politik akan memilih kandidat yang dicalonkan oleh partainya.

\section{Identifikasi Partai: Partisanship dan Orientasi Isu}

Partisanship (keberpihakan) dan orientasi isu adalah salah satu konsep dasar dalam perilaku memilih dalam model psikologis. Party ID terbentuk kalau identitas partai (ideologi, program dan kandidat) jelas wujudnya; partai yang jelas lewat sosialisasinya dan institusionalisasinya ke masyarakat yang dalam jangka panjang akan membangun partisanship; terakhir, adalah isu atau informasi (kampanye) menjelang pemilihan.

Sebagaimana teori funnel causality (lihat gambar 1), teori corong ini menjelaskan bahwa walaupun karakteristik sosial dan demografis di mulut corong, pada gilirannya, pilihan pengaruh seseorang berasal dari identifikasi partai. Partisanship dipandang memengaruhi persepsi individu beserta dengan evaluasi isu-isu dan kandidat dan pada akhirnya diujung corong, sebagai pilihan suara itu sendiri. Namun, sebagaimana batasan konsep yang telah dikemukakan sebelumnya, maka tulisan ini fokus pada identifikasi partai dari warga yang memilih pasangan Sayang dalam Pilgub Sulawesi Selatan tahun 2013. Adapun instrumen-instrumen berdasarkan bagan funnel causality yang dapat memengaruhi pilihan individu: kesesuaian dengan ideologi partai politik, loyalitas kelompok, pandangan terhadap isu-isu, pengetahuan politik (media dan kebijakan pemerintah), penilaian terhadap kandidat dari partai. Namun, banyak hal yang belum dijelaskan dengan lebih baik dalam tulisan ini. Kekurangan data lapangan adalah salah satu penyebabnya, akan tetapi berdasarkan data exit poll dari survei LSI (Lembaga Survei Indonesia) diharapkan cukup mampu menjelaskan permasalahan tersebut (lihat tabel 7, 8, 9, dan 10). Dalam survei yang diadakan oleh LSI diperoleh kesimpulan sebagai berikut. ${ }^{7}$

Pertama, keunggulan pasangan Sayang juga berkaitan dengan preferensi terhadap partai politik. Misalnya mayoritas (80\%) dari pemilih Golkar mendukung Sayang. Begitu halnya dengan partai lain, pemilih cenderung mengidentikkan diri dengan partai yang didukungnya dengan memilih kandidat, misalnya di Partai Demokrat (lihat tabel 7). Hal ini erat kaitannya dengan partisanship, dimana di tingkat mikro atau individu, partisanship dipandang sebagai penjelasan terbaik untuk konsistensi suara individu. Walaupun kandidat dan isu-isu bervariasi dari pemilu ke pemilu, sebagian besar pemilih telah ditemukan untuk tetap setia kepada partai sepanjang karir mereka dalam pemungutan suara. Meskipun dimungkinkan adanya pembelotan, mayoritas pemilih mempertahankan ikatan psikologis kepada partai, sehingga kecenderungan identifikasi ini diyakini terletak sebagai jantung konsistensi suara pemilih. Realita ini dapat dilihat dalam kasus di Luwu Timur, dimana seluruh pemilih partai juga memilih kandidat yang diusung oleh partainya (lihat grafik 1).

Selain itu, mesin partai diasumsikan mampu berfungsi dengan mensosialisasikan kandidat. Seperti diketahui di kedua kabupaten yang diteliti, bupati yang menjabat adalah

7 Press Rilis Quick Count Pilgub Sulsel, 22 Januari 2013 (www.lsi.or.id). 
Tabel 7.

Persentase Calon yang Dipilih Menurut Massa Pemilih Partai

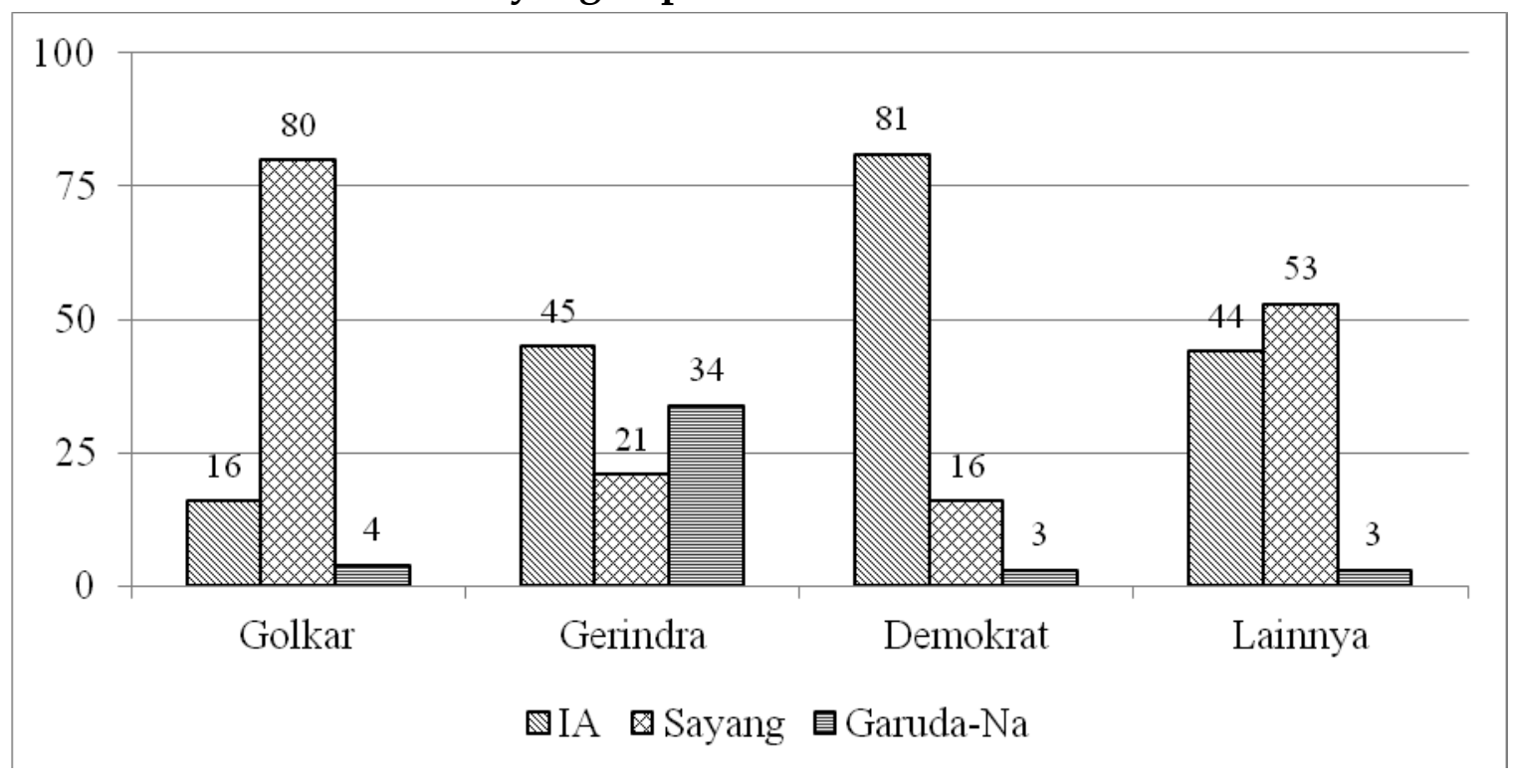

Sumber: $L S I$

fungsionaris partai Golkar. Di Luwu Timur terdapat Andi Hatta Marakarma sebagai Bupati dan Ketua DPD II Partai Golkar Luwu Timur, sedangkan di Pinrang berdiri Andi Aslam Patonangi sebagai salah satu kader Golkar. Kedua pejabat publik tersebut sangat getol mengkampanyekan pasangan Sayang dalam Pilgub lalu. Di Luwu Timur, misalnya, Andi Hatta Marakarma masuk dalam juru kampanye pasangan petahana ini, bahkan memilih cuti dan meninggalkan rumah jabatan selama mengikuti kampanye Sayang. ${ }^{8}$

Kedua, tingkat kepuasan pemilih terhadap kinerja Syarul Yasin Limpo sebagai Gubernur Sulsel sangat tinggi, sekitar 93 persen (lihat tabel 8). Ini sangat berpengaruh terhadap perolehan suara Syahrul Yasin Limpo-Agus Arifin Nu'mang secara keseluruhan. Pemilih di Sulawesi Selatan ternyata telah menggunakan pandangan terhadap isu-isu, menggunakan pengetahuan politik dengan melihat kebijakan pemerintah sebagai penilaian terhadap kandidat dari partai. Pemilih yang puas dengan kinerja incumbent lebih mendukung

8 www.celebesonline.com.
Sayang, sebaliknya pemilih yang tidak puas lebih mendukung IA (lihat tabel 9). Kebijakan pendidikan dan kesehatan gratis, nampaknya menjadi faktor kepuasan masyarakat dalam melihat kinerja pemerintah yang dijalankan oleh Sayang sebagai petahana.

Ketiga, faktor etnis terlihat memiliki pengaruh yang kecil. Meskipun berasal dari kelompok etnis Makassar, namun Syahrul ternyata juga unggul pada etnis Bugis dan etnis Luwu (lihat tabel 10). Begitu halnya pada faktor kedaerahan, pasangan Sayang mampu menang dalam daerah Luwu Raya sebagai basis IA, dan juga menang di daerah Ajatappareng sebagai basis Garuda-Na.

Singkatnya, perilaku memilih dalam kasus Pilgub Sulawesi Selatan tahun 2013, berangkat dari pandangan kausalitas yang dipengaruhi identifikasi partai dengan orientasi afektif (partisanship) sebagai dasar pilihan, sedangkan masalah orientasi isu juga memengaruhi identifikasi partai (kognitif). Pengetahuan politik masyakat ditandai dengan adanya penilaian kinerja pemerintahan. Pengaruh public sphere yang kian terbuka dewasa ini, misalnya media, menjadi salah satu ruang 
Tabel 8.

Persentase Kepuasan Kinerja Incumbent

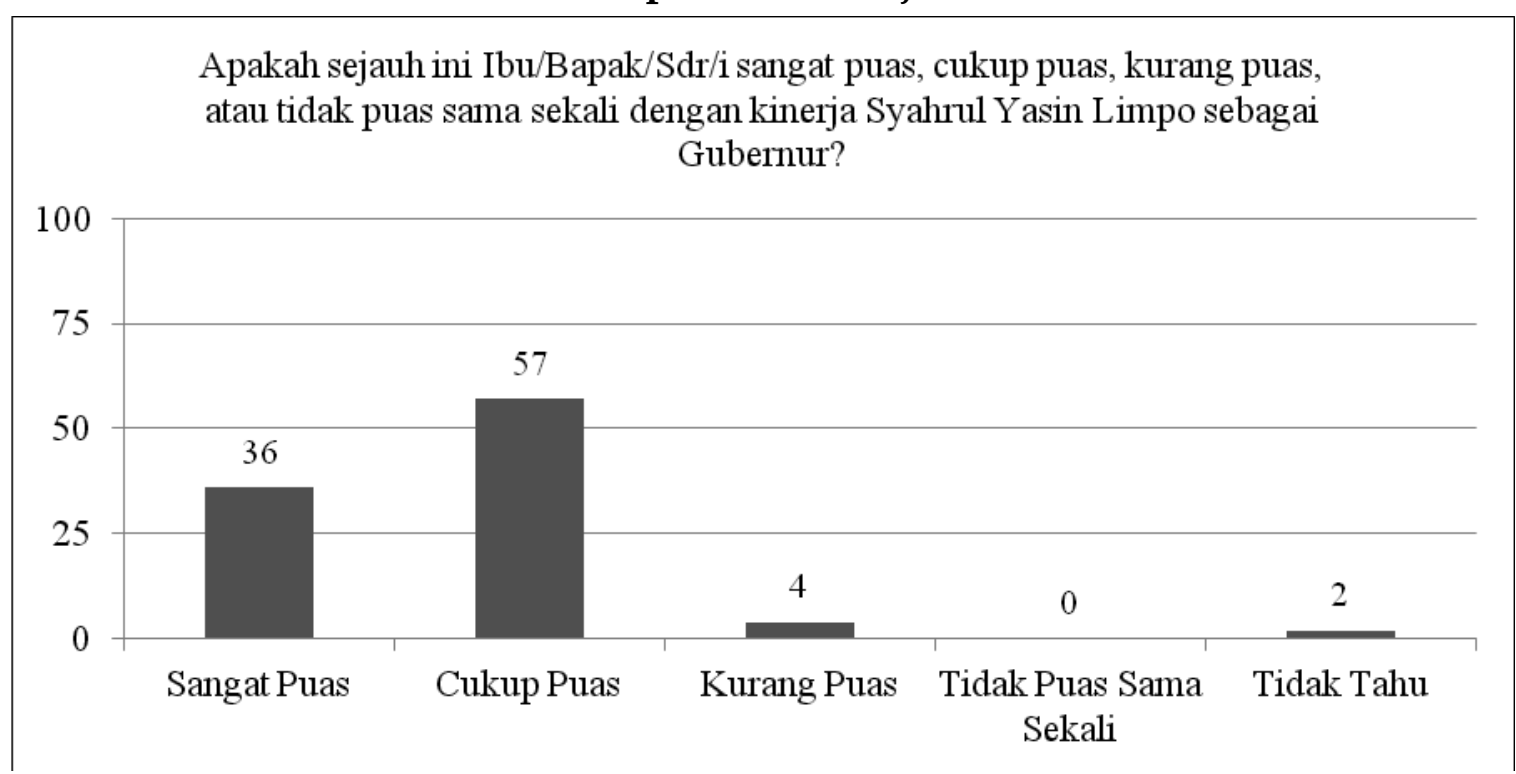

Sumber: LSI

Tabel 9.

Persentase Calon yang Dipilih Berdasarkan Kepuasan Kinerja Incumbent

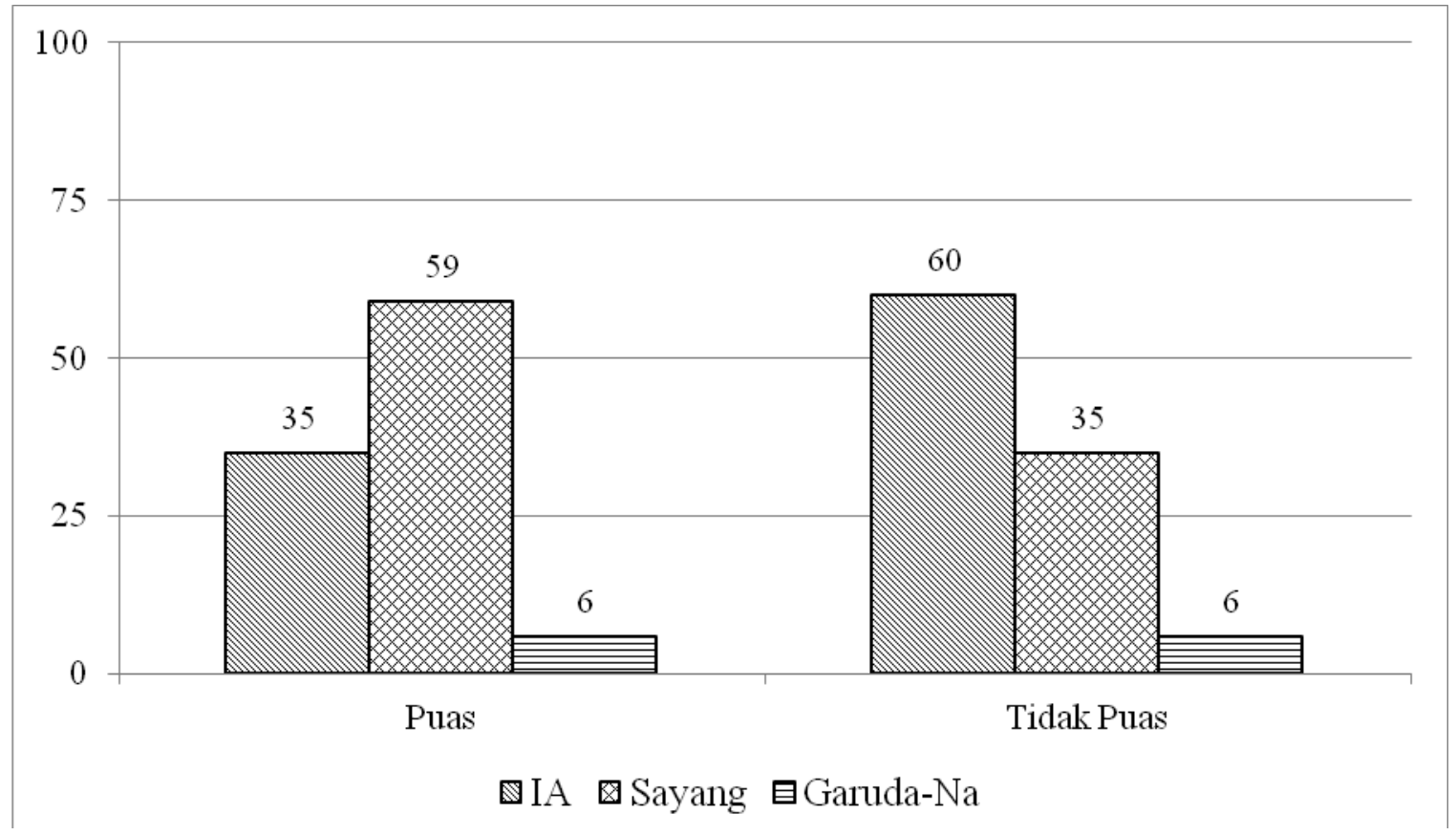

Sumber: LSI

pembelajaran politik tersebut. Geopolitik dalam Pilgub Sulawesi Selatan tahun 2013 menjadi lemah, tidak cukup signifikan dalam memengaruhi pilihan politik warga, namun tidak benar-benar hilang sama sekali.

\section{Kesimpulan}

Identifikasi partai telah menemukan jati dirinya dalam politik lokal di Sulawesi Selatan. Pemilih tidak lagi dominan melihat faktor kedekatan (proximity), baik kedekatan etnik 
Tabel 10.

Persentase Calon yang Dipilih Menurut Etnis

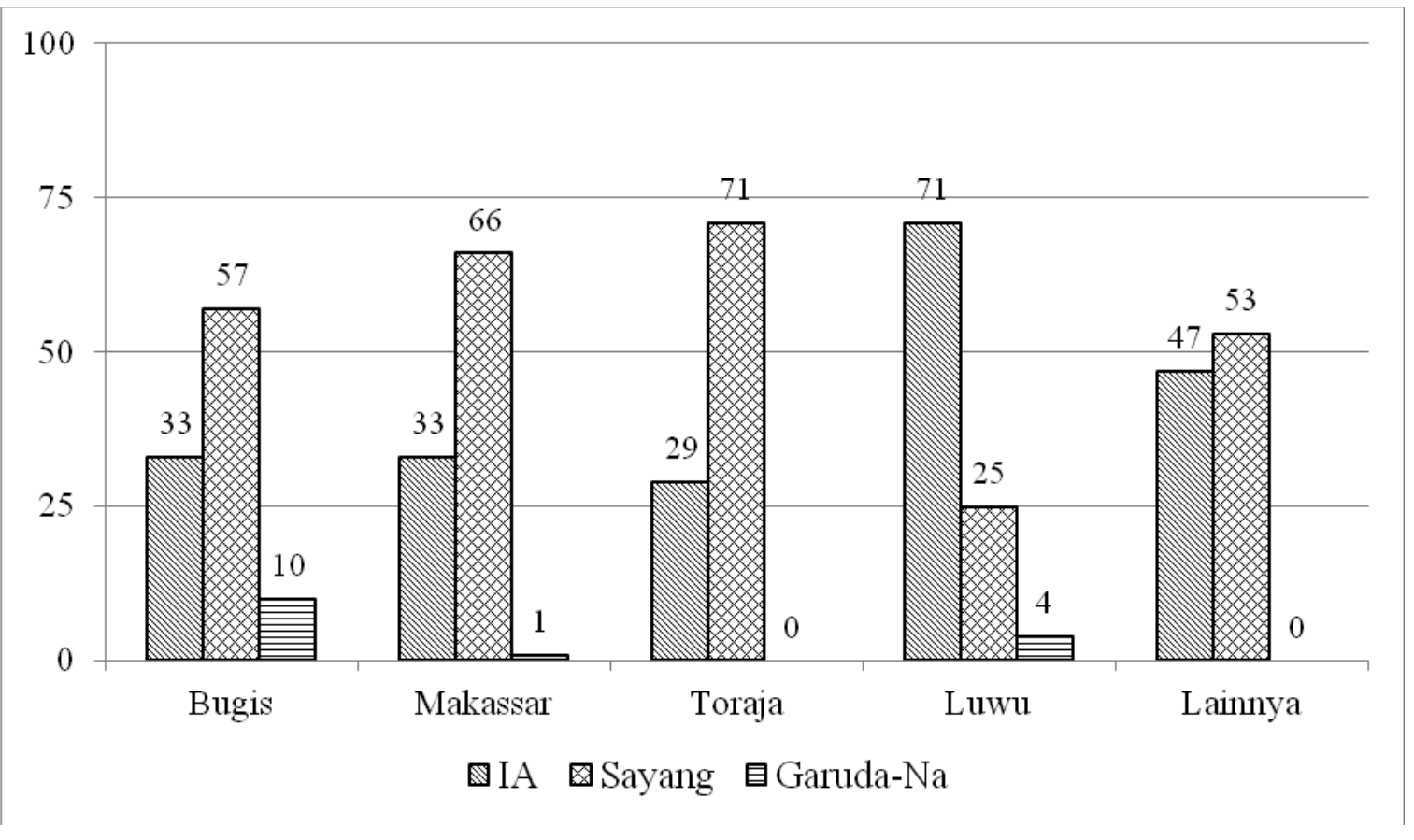

Sumber: $L S I$

maupun daerah dalam menentukan pilihan suara. Pemilih cenderung mengidentikkan diri dengan partai, yang kemudian menentukan pilihan suaranya kepada kandidat yang diusung oleh partainya. Evaluasi terhadap realita politik melalui asumsi kepuasan terhadap kepemimpinan incumbent, menjadi salah satu faktor lain yang memengaruhi perilaku memilih. Intinya adalah identifikasi partai dalam determinan afektif dan kognitif.

Selain itu, di dua kabupaten yang diteliti khususnya pasangan yang memenangkan Pilgub 2013, nampak jelas adanya straightticket voting, dimana hampir dipastikan bahwa warga yang memilih dalam partai koalisi di Pileg DPRD provinsi tahun 2009, juga memilih kandidat pasangan Sayang di Pilgub 2013. Sementara itu, split-ticket voting di dua kabupaten tersebut jumlahnya hampir sama yakni 5,50 persen dan 4,54 persen. Persentase pemilih ini berasal dari partai yang berbeda yang kemudian mengalihkan suaranya kepada pasangan Sayang berdasarkan orientasi isu
- kepuasaan terhadap kinerja atau programprogram dari pasangan calon yang menang.

Kesimpulan bahwa tokoh-tokoh politik yang dikenal oleh masyarakat di tingkat lokal dengan jaringan personal yang kuat ataupun disfungsionalitas partai, dimana partai hanya memainkan peran kecil dalam nasib kandidat untuk menang dalam Pilkada (Buehler, 2009; Choi, 2009), tidak begitu relevan dalam penelitian ini. Pada kedua kabupaten yang diteliti di atas, tokoh politik yang telah berakar di kabupaten, terbukti tidak mampu untuk menang. Sedangkan, mesin partai memiliki peran yang signifikan dalam memobilisasi pilihan politik pemilih di dua kabupaten tersebut.

Namun, apakah bangkitnya fungsionalisasi partai kemudian akan menjadikan demokrasi Indonesia secara keseluruhan akan berjalan sebagaimana mestinya, masih merupakan keraguan. Kesimpulan Mujani dan Liddle (2010) sepertinya masih bertahan bahwa demokrasi Indonesia terlalu tergantung pada liku- 
liku perekrutan kepemimpinan. Mudahnya elit politik menjadi "kutu loncat", beralih partai karena kepentingan kekuasaan belaka, sebagaimana yang dilakukan oleh kandidat yang berkompetisi dalam Pilgub Sulawesi Selatan tahun 2013. Nampaknya, tumbuhnya kesadaran ideologis partai oleh para pemilih tidak dibarengi oleh kesadaran ideologis elit partai. Selain itu, dibalik itu semua, terdapat hal yang menarik apabila mengajukan pertanyaan bagaimana dengan Pemilihan Presiden (Pilpres) di tahun 2014 dengan melihat realita ini? Walaupun argumentasi ini mungkin masih dianggap kurang kuat apabila membaca nasional dari lokal dalam kaitannya dengan perilaku memilih, realita kontemporer di Sulawesi Selatan telah memberikan gambaran awal bahwa pemilih Indonesia telah memulai mengidentikkan dirinya dengan partai dalam menentukan kandidat pilihannya. Jadi, siapapun yang memiliki koalisi partai terbesar (jumlah suara legislatif), maka akan melenggangkan calon presidennya ke istana untuk 2014-2019.

\section{Daftar Pustaka}

Ananta, A., E. N. Arifin \&,L. Suryadinata (2004). Indonesian Electoral Behaviour: A Statistical Perspective. Singapore: ISEAS.

Bartels, L. M. (2012). “The Study of Electoral Behavior" dalam Jan E. Leighley (ed) The Oxford Handbook of American Elections and Political Behavior. Oxford: Oxford University Press.

Buehler, M. (2009) “The Rising Importance of Personal Networks In Indonesian Local Politics: An Analysis of District Government Head Elections in South Sulawesi in 2005" dalam M. Erb \& P. Sulistiyanto (eds) Deepening Democracy in Indonesia? Direct Elections for Local Leaders (Pilkada). Singapura: ISEAS Publishing.

Campbell, A, P. E. Converse, W. E. Miller, \& D. E. Stokes. (1960). The American Voter. New York: Wiley.
Celebes Online. (2013). Bupati Lutim Sengaja Cuti Demi Sayang, (Online), (http://www. celebesonline.com/index/2013/01/12/ bupati-lutim-sengaja-cuti-demi-sayang/, diakses 1 April 2013).

Choi, N. (2009). “Batam's 2006 Mayoral Election: Weakened Political Parties and Intensified Power Struggle in Local Indonesia" dalam M. Erb \& P. Sulistiyanto (eds) Deepening Democracy in Indonesia? Direct Elections for Local Leaders (Pilkada). Singapura: ISEAS Publishing.

Dalton, R. J. (2002). Citizen Politics: Public Opinion and Political Parties in Advanced Industrial Democracies. New York: Chatham House Publishers.

Erman, E. (2007). "Indikasi Patrimonialisme dan Klientalisme dalam Proses Pilkada" dalam Syarif Hidayat \& Hari Susanto (eds) Bisnis dan Politik di Tingkat Lokal: Pengusaha, Penguasa, dan Penyelenggaraan Pemerintahan Daerah pasca Pilkada. Jakarta: LIPI Press.

Gaffar, A. (1992). Javanese Voters: A Case Study of Election Under A Hegemonic Party System. Yogyakarta: Gadjah Mada University Press.

Hanif, H. (2009). Politik Klientelisme Baru dan Dilema Demokratisasi di Indonesia. Jurnal Ilmu Sosial dan Ilmu Politik. Vol. 12 No. 3 Edisi Maret 2009, pp. 257-390.

King, D. Y. (2003). Half-hearted Reform: Electoral Institutions and the Struggle for Democracy. Connecticut: Praeger.

KPUD Kabupaten Luwu Timur. Lampiran 2 Model DB1-KWK KPU (Rekapitulasi Hasil Penghitungan Suara Pemilihan Gubernur dan Wakil Gubernur Sulawesi Selatan Tahun 2013 Di Tingkat Kabupaten/Kota).

KPUD Kabupaten Pinrang. Lampiran 2 Model DB1-KWK KPU (Rekapitulasi Hasil Penghitungan Suara Pemilihan Gubernur dan Wakil Gubernur Sulawesi Selatan Tahun 2013 Di Tingkat Kabupaten/Kota). KPUD Provinsi Sulawesi Selatan. Lampiran DC-1 DPRD Provinsi Dapil 6 (Rincian Perolehan Suara Sah dan Tidak Sah Partai 
Politik dan Calon Anggota DPRD Provinsi 2009).

KPUD Provinsi Sulawesi Selatan. Lampiran DC-1 DPRD Provinsi Dapil 7 (Rincian Perolehan Suara Sah dan Tidak Sah Partai Politik dan Calon Anggota DPRD Provinsi 2009).

Lau, R. R. \& D. P. Redlawsk (2006). How Voters Decide: Information Processing in Election Campaigns. Cambridge: Cambridge University Press.

Lembaga Survei Indonesia. (2012). Hasil Quick Count Pilkada Provinsi Sulawesi Selatan (Sulsel) Selasa 22 Januari 2013. (Online), (http://www.lsi.or.id/riset/428/quickcount_ sulsel_2013, diakses 2 Agustus 2013).

Liddle, R.W. (2012). "Memperbaiki Mutu Demokrasi: Sumbangan Ilmu Politik" dalam I. Ali-Fauzi \& R. Panggabean (eds) Memperbaiki Mutu Demokrasi Di Indonesia. Jakarta: PUSAD Yayasan Wakaf Paramadina.

Liddle, R.W. \& S. Mujani (2007). Leadership, Party, and Religion: Explaining Voting Behavior in Indonesia. Comparative Political Studies. Vol. 40 No. 7 Edisi Juli, pp. 832857.

Luwu Raya Net. (2013). Ketat, Sentimen Kultural Jadi Wilayah Pertarungan. (Online), (http://www.luwuraya.net/2012/10/ ketat-sentimen-kultural-jadi-wilayahpertarungan/ diakses 1 April 2013).

Mujani, S. \& R. W. Liddle (2010). Personalities, Parties, and Voters. Journal of Democracy. Vol. 21 No. 2 Edisi April, pp. 35-49.

Mujani, S., R. W. Liddle \& K. Ambardi (2012). Kuasa Rakyat. Jakarta: Mizan.
Nordholt, H. S. (2005) “Desentralisasi di Indonesia: Peran Negara Kurang Lebih Demokratis?" dalam J. Harris, K. Stokke \& O, Tornquist (eds) Politisasi Demokrasi: Politik Lokal Baru. Jakarta: Demos.

Rakyat Sulsel Online. (2012). Kumpulkan 16 Parpol, IA Patahkan Sayap Garuda'NA. (Online), (http://www.rakyatsulsel.com/ kumpulkan-16-parpol-ia-patahkan-sayapgarudana.html, diakses 2 Agustus 2013).

Roth, D. (2008). Studi Pemilu Empiris: Sumber, Teori, Instrumen dan Metode. Jakarta: Friderich-Naumann-Stiftung fur die Freiheit.

Suwadi Idris Amir Institute. (2013). Rudi-Nawir Optimis Mampu Pecahkan Suara Ia dan Sayang. (Online), (http://www.suwadiidrisamir. com/2012/05/rudi-nawir-optimis-mampupecahkan-ia.html, diakses 1 April 2013).

Tomsa, D. (2008). Party Politicsand Democratization in Indonesia: Golkar in the post-Suharto era. New York: Routledge.

Ufen, A. (2008). From Aliran to Dealignment: Political Parties in post-Suharto Indonesia. South East Asia Research, Volume 16, Number 1, March 2008 , pp. 5-41.

Wawancara:

Irfan Yahya (asisten pribadi Azis Qahhar Mudzakkar), wawancara tanggal 11 September 2013.

Karyadi (Ketua DPC PKS Tomoni Timur, Kabupaten Luwu Timur), wawancara tanggal 7 Agustus 2013.

Muhammad Ayyub (anggota KPUD Luwu Timur sejak tahun 2008-2018), wawancara tanggal 12 Agustus 2013. 